\title{
Deinococcus gobiensis sp. nov., an extremely radiation-resistant bacterium
}

\author{
Menglong Yuan, ${ }^{1,2}+$ Wei Zhang, ${ }^{1}+$ Shiming Dai, ${ }^{1}$ Jing Wu, ${ }^{1}$ \\ Yingdian Wang, ${ }^{2}$ Tianshen Tao, ${ }^{3}$ Ming Chen ${ }^{1}$ and Min Lin ${ }^{1}$ \\ ${ }^{1}$ Biotechnology Research Institute, Chinese Academy of Agricultural Sciences, Beijing 100081 , \\ PR China \\ ${ }^{2}$ College of Life Science, Beijing Normal University, Beijing 100875, PR China \\ ${ }^{3}$ China Center for Type Culture Collection, Wuhan University, Wuhan 430072, PR China
}

Correspondence

Min Lin

linmin57@vip.163.com

\begin{abstract}
A Gram-positive, non-motile, spherical, red-pigmented and facultatively anaerobic bacterium, designated strain $1-0^{\top}$, was isolated from a sand sample of the Gobi desert in Xinjiang Autonomous Region, China. Phylogenetic analysis based on 16S rRNA gene sequences indicated that this isolate represents a novel member of the genus Deinococcus, with low sequence similarities (<94\%) to recognized Deinococcus species. The major cellular fatty acids were $\mathrm{C}_{16: 1} \omega 7 \mathrm{c}$ and $\mathrm{C}_{16: 0}$. Its polar lipid profile contained several unidentified glycolipids, phosphoglycolipids, phospholipids, pigments and an aminophospholipid. The peptidoglycan type was Orn-Gly $2(A 3 \beta)$ and the predominant respiratory quinone was MK-8. The DNA G+C content was 65.4 mol\%. DNA-DNA relatedness between strain $1-0^{\top}$ and Deinococcus radiodurans ACCC $10492^{\top}$ was $37 \%$. The strain was shown to be extremely resistant to gamma radiation ( $>15 \mathrm{kGy}$ ) and UV light $\left(>600 \mathrm{~J} \mathrm{~m}^{-2}\right.$ ). On the basis of the phylogenetic, chemotaxonomic and phenotypic data presented, strain $1-0^{\top}$ represents a novel species of the genus Deinococcus, for which the name Deinococcus gobiensis sp. nov. is proposed. The type strain is $1-0^{\top}\left(=\right.$ DSM $21396^{\top}=$ CGMCC $\left.1.7299^{\top}\right)$.
\end{abstract}

The genus Deinococcus, which was described by Brooks \& Murray (1981), comprises 31 species with validly published names at the time of writing (http://www.bacterio.cict.fr/d/ deinococcus.html). These species have been isolated from a wide range of environments, e.g. desert soil (Rainey et al., 2005; de Groot et al., 2005), aquifers (Suresh et al., 2004), the plant rhizosphere (Lai et al., 2006), hot springs (Ferreira et al., 1997) and airborne dust (Shashidhar \& Bandekar, 2006; Weon et al., 2007). Most members of the genus are strictly aerobic, have optimum growth temperatures in the range $25-35{ }^{\circ} \mathrm{C}$ and form red, pink, light-pink or reddish colonies. Their extreme resistance to ionizing radiation (10 kGy), UV light $\left(600 \mathrm{~J} \mathrm{~m}^{-2}\right)$ and desiccation (years) is a distinctive characteristic of this genus (Makarova et al., 2007). This resistance has been attributed to a highly proficient DNA repair system, and it seems

†These authors contributed equally to this work.

The GenBank/EMBL/DDBJ accession number for the $16 \mathrm{~S}$ rRNA gene sequence of strain $1-0^{\top}$ is EU427464.

Micrographs of colonies and cells of strain $1-0^{\top}$, a $16 \mathrm{~S}$ rRNA gene sequence-based maximum-parsimony tree, the fatty acid profile of strain $1-0^{\top}$ and a table of $16 \mathrm{~S}$ rRNA gene sequence similarities to related strains are available as supplementary material with the online version of this paper. likely that radiation resistance evolved as a consequence of chronic exposure to non-radioactive forms of DNA damage, such as desiccation (Makarova et al., 2001).

In the course of the study of stress-resistant bacteria from arid environments, a novel Deinococcus isolate was obtained from the upper sand layers of the Gobi desert, Xinjiang, China, where bacteria are exposed to cycles of high and low temperatures and to prolonged desiccation. In this paper, we report on the taxonomic characterization of this radiation-resistant, red-coloured strain, designated $\mathrm{I}-0^{\mathrm{T}}$, which was obtained from a mixed sand sample. After exposure of the sample to $10 \mathrm{kGy}$ gamma radiation from a ${ }^{60} \mathrm{Co}$ source (CAIC), it was enriched in $50 \mathrm{ml}$ TGY medium ( $1.0 \%$ peptone, $0.5 \%$ yeast extract, $0.1 \%$ glucose) at $30{ }^{\circ} \mathrm{C}$ with shaking at 200 r.p.m. for up to 5 days, followed by isolation of surviving red-colony-forming bacteria on TGY agar plates (TGY medium with $1.5 \%$ agar).

Morphology of cells grown for 24-48 h on TGY agar was examined by zoom stereo microscopy (model SZX7; Olympus), light microscopy (model BX-51; Olympus), scanning electron microscopy (model S-570; Hitachi) and transmission electron microscopy (model H-7500; Hitachi). Gram staining was carried out using the modified 
method of Cowan (1974). Physiological characterization and additional biochemical tests were performed as described by Anderson et al. (1956).

Whole-cell hydrolysates were prepared as described by Hasegawa et al. (1983). Fatty acid methyl esters were analysed by using the trimethyl sulfonium hydroxide method of Butte (1983). Polar lipid analysis, cell-wall peptidoglycan analysis and quinone analysis were carried out according to the methods outlined by Zhang et al. (2007) and performed at the Institute of Microbiology of Yunnan Province.

Genomic DNA of strain $\mathrm{I}-0^{\mathrm{T}}$ was extracted using a TIANamp bacteria DNA kit (Tiangen) according to the manufacturer's instructions. The $16 \mathrm{~S}$ rRNA gene was amplified by PCR with bacterial universal primers F27 and R1492, which were adapted from primers $\mathrm{fD} 1$ and $\mathrm{rP} 1$ (Weisburg et al., 1991), and then ligated into the pSURE-T vector (Galen), followed by sequencing by Takala Co. (Dalian, China). The DNA G $+\mathrm{C}$ content was determined by the thermal denaturation method (Marmur \& Doty, 1962) and was calculated by using the equation of Owen \& Lapage (1976). Escherichia coli K-12 CGMCC 1.3065 (DNA $\mathrm{G}+\mathrm{C}$ content $50.6 \mathrm{~mol} \%$ ) was used as a control. DNADNA hybridization studies were carried out by using the fluorometric microdilution plate method (Ezaki et al., 1988; Sawabe et al., 1998).

To determine resistance of the culture to gamma radiation, cells were harvested by centrifugation at $5000 \mathrm{~g}$ for $5 \mathrm{~min}$ and then washed twice with $100 \mathrm{mM}$ potassium phosphate buffer ( $\mathrm{pH}$ 7.0). Four millilitres of the suspension was exposed to different doses $(0,5,10$ and $15 \mathrm{kGy})$ of gamma radiation from a ${ }^{60} \mathrm{Co}$ source $\left(6 \mathrm{kGy} \mathrm{h}{ }^{-1}\right.$; BNU) in a $15 \mathrm{ml}$ EP tube. Irradiated cultures were serially diluted and $100 \mu \mathrm{l}$ aliquots were spread on TGY agar plates. After incubation at $30{ }^{\circ} \mathrm{C}$ for $3-4$ days, the total c.f.u. $\mathrm{ml}^{-1}$ was determined. To determine the resistance of the isolate to UV light, UV survival curves were obtained according to the method of Liu et al. (2008). For both experiments, E. coli K-12 CGMCC 1.3065 served as a negative control and Deinococcus radiodurans ACCC $10492^{\mathrm{T}}$ served as a positive control.

Strain $\mathrm{I}-0^{\mathrm{T}}$ was a Gram-positive, non-spore-forming coccus. It grew well on TGY agar in an incubator and could grow on nutrient agar in an anaerobic chamber, but did not grow on Luria-Bertani agar. Colonies on TGY plates were pink-red, circular, opaque and convex with regular edges (Supplementary Fig. S1, available in IJSEM Online). Cells were $1.0-2.2 \mu \mathrm{m}$ in diameter, occurring singly and in tetrad forms and usually in pairs, and did not form spores (Supplementary Fig. S2). The ultrastructure of strain I- $0^{\mathrm{T}}$ was similar to that of Deinococcus murrayi ALT$1 b^{\mathrm{T}}$ (Ferreira et al., 1997), which showed a cell wall with several layers and a large electron-dense granule (Supplementary Fig. S3). Strain $\mathrm{I}-0^{\mathrm{T}}$ was positive for catalase, oxidase and urease and reduction of nitrate to nitrite, but negative for arginine dihydrolase, indole production and the Voges-Proskauer test. Strain $\mathrm{I}-0^{\mathrm{T}}$ could degrade gelatin, starch and casein and utilized a number of substrates as sole carbon sources for growth. These sole carbon source tests showed distinct results for strain $\mathrm{I}-0^{\mathrm{T}}$ and other Deinococcus species (Table 1 and the species description).

The whole-cell sugars contained mainly glucose and small quantities of ribose. The major cellular fatty acids were straight-chain $\mathrm{C}_{16: 1} \omega 7 \mathrm{c}(42.07 \%)$ and $\mathrm{C}_{16: 0}(35.06 \%)$ (Table 1, Supplementary Table S1). This combination allows strain $\mathrm{I}-\mathrm{O}^{\mathrm{T}}$ to be distinguished from recognized species of the genus Deinococcus. Cell-wall peptidoglycan analysis showed that the cell wall contained L-ornithine as the diamino acid $(\mathrm{A} 3 \beta)$. The major respiratory quinone in strain $\mathrm{I}-0^{\mathrm{T}}$ was $\mathrm{MK}-8$, as in all recognized Deinococcus species.

As shown in Fig. 1, the polar lipid profile of strain $\mathrm{I}-0^{\mathrm{T}}$ consisted of three unidentified glycolipids, four phosphoglycolipids, three phospholipids, two pigment spots and an aminophospholipid. The polar lipid profile of strain $\mathrm{I}-0^{\mathrm{T}}$ was dominated by phosphoglycolipids, which co-migrated with those found in other Deinococcus species (Embley et al., 1987; Ferreira et al., 1997; Suresh et al., 2004; Lai et al., 2006; Rainey et al., 2007; Zhang et al., 2007). The chromatographic behaviour of the polar lipids PL, APL, PGL1-2 and GL3 and pigments PIG1-2 of strain $\mathrm{I}-0^{\mathrm{T}}$ was similar to that of the lipid spots PL, APL, PGL1-2 and GL3 and PIG1-2 reported for D. radiodurans AS $1.633^{\mathrm{T}}$ (Zhang et al., 2007). The presence of these lipids extracted from strain $\mathrm{I}-0^{\mathrm{T}}$ confirms that it should be assigned to the genus Deinococcus.

An almost-complete 16S rRNA gene sequence (1470 bp) was determined for strain $\mathrm{I}-0^{\mathrm{T}}$. A FASTA search of the EMBL nucleotide sequence database using this sequence showed relatively low similarity $(<94 \%)$ to sequences from other Deinococcus species (Supplementary Table S2), which indicated that this strain might represent a novel species. Phylogenetic analyses were performed using MEGA version 4 (Tamura et al., 2007). Phylogenetic dendrograms, which showed slightly different phylogenetic topologies, were conducted by the neighbour-joining (Fig. 2) and maximum-parsimony (Supplementary Fig. S4) methods with bootstrap values based on 1000 replications. The $\mathrm{G}+\mathrm{C}$ content of the DNA was 65.4 mol\%. DNA-DNA hybridization tests indicated that the relatedness between strain $\mathrm{I}-0^{\mathrm{T}}$ and $D$. radiodurans ACCC $10492^{\mathrm{T}}$ was $37 \%$.

Survival rates after exposure to various doses of gamma radiation and UV light were analysed for strain $\mathrm{I}-0^{\mathrm{T}}, D$. radiodurans ACCC $10492^{\mathrm{T}}$ and E. coli K-12 CGMCC 1.3065 (Fig. 3). The gamma radiation and UV light survival curves of E. coli K-12 CGMCC 1.3065 dropped most sharply, while the two Deinococcus strains were significantly resistant to gamma radiation and UV light. Compared with D. radiodurans ACCC $10492^{\mathrm{T}}$, strain $\mathrm{I}-0^{\mathrm{T}}$ showed higher resistance to gamma radiation and UV light. 
Table 1. Properties of strain $1-0^{\top}$ useful for differentiation from type strains of related species of genus Deinococcus

Strains: 1 , strain $\mathrm{I}-0^{\mathrm{T}}$ (data from this study); 2, D. radiodurans $\mathrm{R} 1^{\mathrm{T}}$ [data for carbon utilization, cell morphology, pigmentation and Gram reaction from this study and data for fatty acids from Zhang et al. (2007) using strain ACCC $10492^{\mathrm{T}}$; other data from Brooks \& Murray (1981)]; 3, D. hohokamensis KR-40 ${ }^{\mathrm{T}}$; 4, D. navajonensis KR-114 (data in columns 3 and 4 from Rainey et al., 2005); 5, D. indicus Wt/1 ${ }^{\mathrm{T}}$ (Suresh et al., 2004); 6, D. deserti VCD115 ${ }^{\mathrm{T}}$ (de Groot et al., 2005); 7, D. grandis DSM $1963^{\mathrm{T}}$ (Oyaizu et al., 1987; Suresh et al., 2004). +, Positive; -, negative; w, weakly positive; ND, no data available.

\begin{tabular}{|c|c|c|c|c|c|c|c|}
\hline Characteristic & 1 & 2 & 3 & 4 & 5 & 6 & 7 \\
\hline Cell morphology & Coccus & Coccus & Coccus & Rod & Rod & Rod & Rod \\
\hline Demand for oxygen & $\begin{array}{c}\text { Facultative } \\
\text { anaerobe }\end{array}$ & Strict aerobe & Aerobe & Aerobe & Strict aerobe & Strict aerobe & Aerobe \\
\hline Cytochrome oxidase & + & + & + & + & - & ND & - \\
\hline \multicolumn{8}{|l|}{$\begin{array}{l}\text { Carbon source } \\
\text { utilization }\end{array}$} \\
\hline D-Fucose & - & + & - & + & ND & ND & ND \\
\hline Raffinose & + & $\mathrm{W}$ & - & - & + & ND & - \\
\hline D-Xylose & - & - & - & - & ND & - & ND \\
\hline Fructose & + & + & - & + & - & + & $\mathrm{ND}$ \\
\hline Major fatty acids (\%) & $\begin{array}{c}16: 1 \omega 7 c(42.1) \\
16: 0(35.1)\end{array}$ & $\begin{array}{c}16: 1 \omega 7 c(39.9) \\
16: 0(14.1) \\
17: 1 \omega 8 c(11.8)\end{array}$ & $\begin{array}{c}16: 1 \omega 7 c(\mathrm{ND}) \\
17: 1 \omega 8 c(\mathrm{ND}) \\
17: 1 \omega 7 c \text { iso } \\
(\mathrm{ND})\end{array}$ & $\begin{array}{c}16: 1 \omega 7 c(\mathrm{ND}), \\
17: 1 \omega 8 c(\mathrm{ND}), \\
17: 1 \omega 7 c \text { iso } \\
(\mathrm{ND})\end{array}$ & 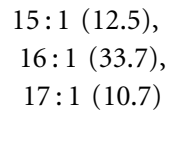 & $\begin{array}{c}16: 1 \omega 7 c(29.4) \\
17: 1 \omega 8 c(14.1)\end{array}$ & $\begin{array}{c}15: 0(13), \\
15: 1(23), \\
16: 1(18)\end{array}$ \\
\hline $\begin{array}{l}\text { DNA G + C content } \\
(\mathrm{mol} \%)\end{array}$ & 65.4 & 67 & 67.9 & 66.4 & 65.8 & 60 & 68.7 \\
\hline
\end{tabular}

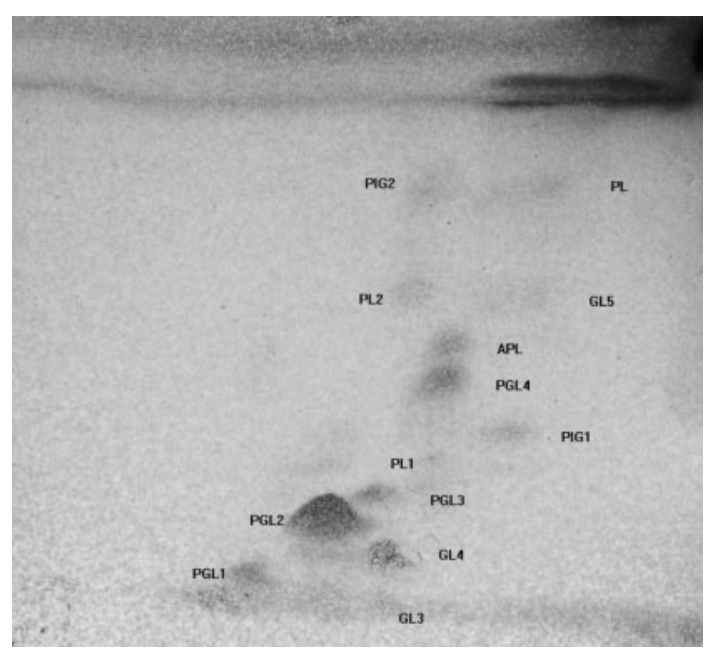

Fig. 1. Polar lipid profile of strain $1-0^{\top}$. GL3-GL5, Unidentified glycolipids; PGL1-PGL4, unidentified phosphoglycolipids; PL, PL1 and PL2, unidentified phospholipids; APL, unidentified aminophospholipid; PIG1 and PIG2, pigments.
In summary, the results of $16 \mathrm{~S}$ rRNA gene sequence comparison and the chemotaxonomic data clearly demonstrate that strain $\mathrm{I}-0^{\mathrm{T}}$ is a member of the genus Deinococcus. On the basis of its distinct phylogenetic position, the presence of the combination of fatty acids $\mathrm{C}_{16: 1} \omega 7 c$ and $\mathrm{C}_{16: 0}$ and its phenotypic characteristics (Table 1), strain I- $0^{\mathrm{T}}$ represents a novel species of the genus Deinococcus, for which the name Deinococcus gobiensis sp. nov. is proposed.

\section{Description of Deinococcus gobiensis sp. nov.}

Deinococcus gobiensis (go.bi.en'sis. N.L. masc. adj. gobiensis pertaining to the Gobi, a great bare-rock desert in Xinjiang Autonomous Region, China, the source of the type strain).

Cells are facultatively anaerobic, Gram-positive, nonspore-forming cocci, $1.0-2.2 \mu \mathrm{m}$ in diameter. Catalaseand oxidase-positive. Reduces nitrate to nitrite. Positive for urease and negative for arginine dihydrolase and indole production. Negative in the Voges-Proskauer test. Grows well on TGY agar at $15-35{ }^{\circ} \mathrm{C}$ (optimum $30{ }^{\circ} \mathrm{C}$ ) and $\mathrm{pH} 7-$ 8; does not grow on $\mathrm{LB}$ agar. The reddish colonies are circular, opaque and convex with regular edges. Glucose, sucrose, lactose, fructose, L-aspartic acid and L-histidine 


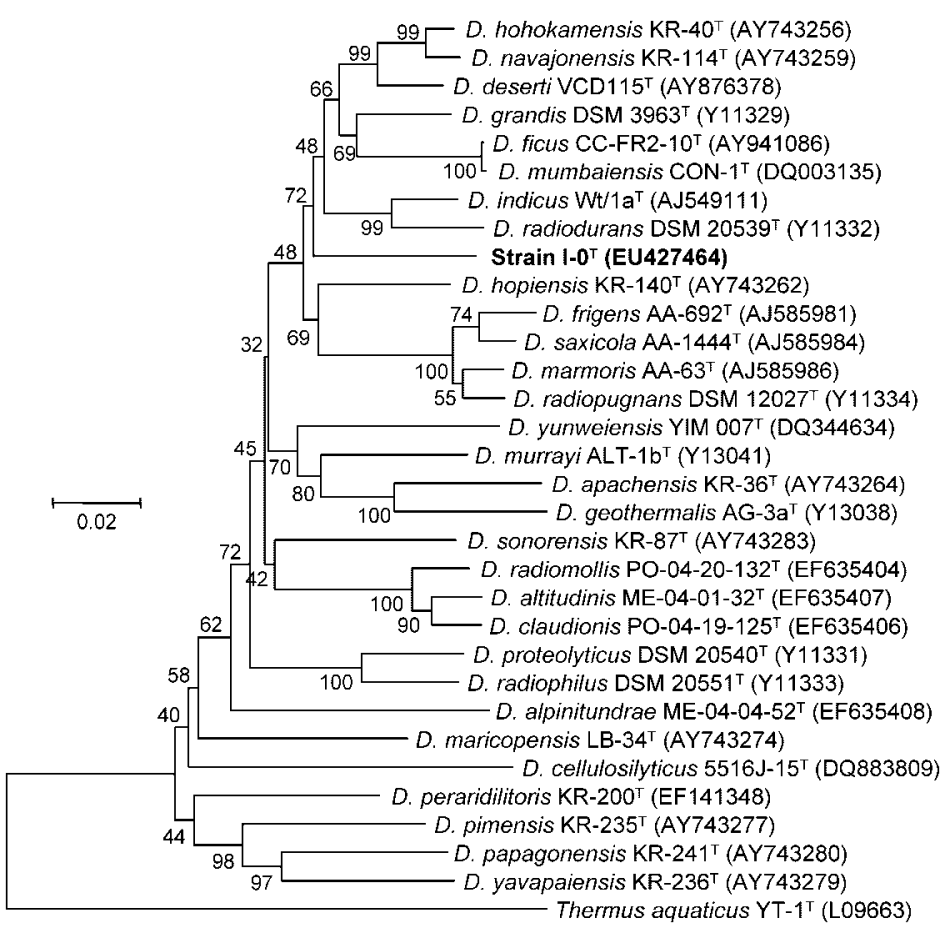

Fig. 2. Neighbour-joining phylogenetic tree constructed from a comparative analysis of 16S rRNA gene sequences showing the relationships of strain $1-0^{\top}$ with other Deinococcus strains. Numbers on branch nodes are percentage bootstrap values. Bar, 0.02 substitutions per nucleotide position. The sequence of Thermus aquaticus $\mathrm{YT}-1^{\top}$ was used as an outgroup.
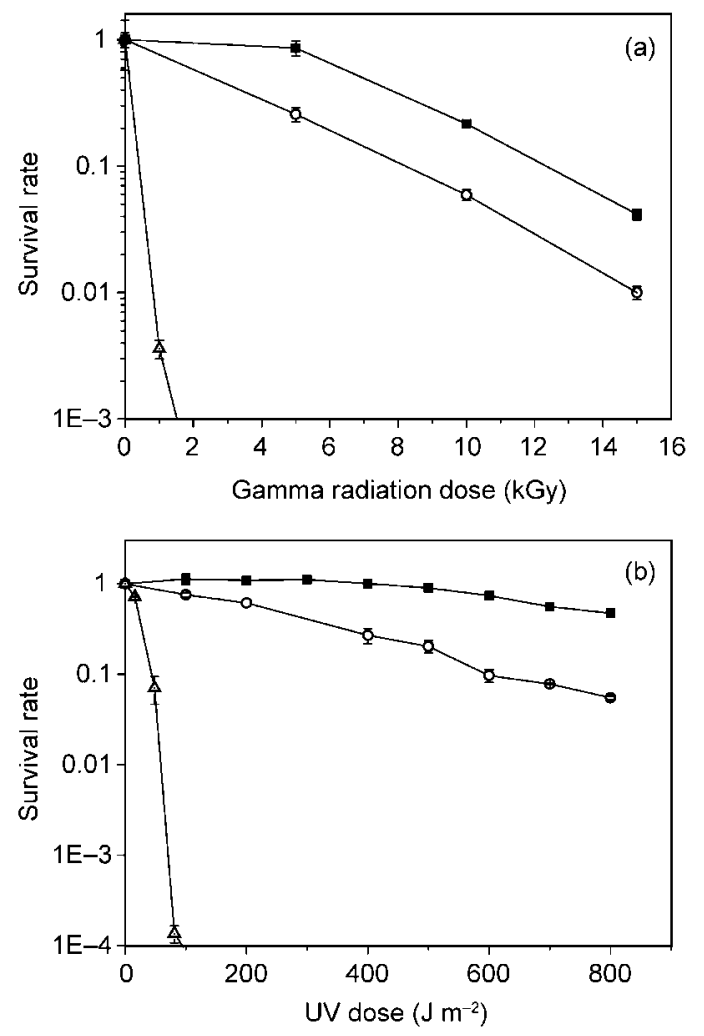

Fig. 3. Survival curves following exposure to gamma radiation (a) and UV light (b) of strain I-O $\mathrm{O}^{\top}(\mathbf{\square}), D$. radiodurans ACCC $10492^{\top}$ $(\bigcirc)$ and $E$. coli K-12 CGMCC $1.3065(\triangle)$. can be utilized as sole carbon sources, but L-arabinose, Dfucose, D-xylose, L-rhamnose, L-tryptophan and L-arginine can not. Gelatin, starch and casein are degraded. The major cellular fatty acids are $\mathrm{C}_{16: 1} \omega 7 c$ and $\mathrm{C}_{16: 0}$. Peptidoglycan type is Orn-Gly $2(\mathrm{~A} 3 \beta)$. The major respiratory quinone is MK-8. The polar lipid profile consists of various unidentified glycolipids, phosphoglycolipids, phospholipids, pigments and an aminophospholipid. The DNA G+C content of the type strain is $65.4 \mathrm{~mol} \%$. The type strain is extremely resistant to gamma radiation $(>15 \mathrm{kGy})$ and UV light $\left(>600 \mathrm{~J} \mathrm{~m}^{-2}\right)$ compared with E. coli K-12 CGMCC 1.3065 and D. radiodurans ACCC $10492^{\mathrm{T}}$.

The type strain is $\mathrm{I}-0^{\mathrm{T}} \quad\left(=\mathrm{DSM} \quad 21396^{\mathrm{T}}=\mathrm{CGMCC}\right.$ $1.7299^{\mathrm{T}}$ ), isolated from a mixed sand sample from the Gobi desert.

\section{Acknowledgements}

The authors wish to thank Professor Xiuzhu Dong (Institute of Microbiology, Chinese Academy of Sciences) for reading the typescript. This work was supported by the Ministry of Science and Technology of China (National Basic Research Program 2007CB707805 and National High-Tech Program 2007AA021305, 2006AA02Z229 and 2006AA020101) and the National Natural Science Foundation of China (grant no. 30670050).

\section{References}

Anderson, A. W., Nordan, H. C., Cain, R. F., Parrish, G. \& Duggan, D. (1956). Studies on a radioresistant Micrococcus. I. Isolation, morphology, cultural, characteristics, and resistance to gamma radiation. Food Technol 10, 575-577. 
Brooks, B. W. \& Murray, R. G. E. (1981). Nomenclature for "Micrococcus radiodurans" and other radiation-resistant cocci: Deinococcaceae fam. nov. and Deinococcus gen. nov., including five species. Int J Syst Bacteriol 31, 353-360.

Butte, W. (1983). Rapid method for the determination of fatty acid profiles from fats and oils using trimethylsulphonium hydroxide for transesterification. J Chromatogr A 261, 142-145.

Cowan, S. T. (1974). Cowan and Steel's Manual for the Identification of Medical Bacteria, 2nd edn. London: Cambridge University Press.

de Groot, A., Chapon, V., Servant, P., Christen, R., Fischer-Le Saux, M., Sommer, S. \& Heulin, T. (2005). Deinococcus deserti sp. nov., a gamma-radiation-tolerant bacterium isolated from the Sahara Desert. Int J Syst Evol Microbiol 55, 2441-2446.

Embley, T. M., O'Donnell, A. G., Watt, R. \& Rostron, J. (1987). Lipid and cell wall amino acid composition in the classification of members of the genus Deinococcus. Syst Appl Microbiol 10, 20-27.

Ezaki, T., Hashimoto, Y., Takeuchi, N., Yamamoto, H., Liu, S.-L., Miura, H., Matsui, K. \& Yabuuchi, E. (1988). Simple genetic method to identify viridans group streptococci by colorimetric dot hybridization and fluorometric hybridization in microdilution wells. J Clin Microbiol 26, 1708-1713.

Ferreira, A. C., Nobre, M. F., Rainey, F. A., Silva, M. T., Wait, R., Burghardt, J., Chung, A. P. \& da Costa, M. S. (1997). Deinococcus geothermalis sp. nov. and Deinococcus murrayi sp. nov., two extremely radiation-resistant and slightly thermophilic species from hot springs. Int J Syst Bacteriol 47, 939-947.

Hasegawa, T., Takizawa, M. \& Tanida, S. (1983). A rapid analysis for chemical grouping of aerobic actinomycetes. J Gen Appl Microbiol 29, 319-322.

Lai, W.-A., Kämpfer, P., Arun, A. B., Shen, F.-T., Huber, B., Rekha, P. D. \& Young, C.-C. (2006). Deinococcus ficus sp. nov., isolated from the rhizosphere of Ficus religiosa L. Int J Syst Evol Microbiol 56, 787791.

Liu, X., Wu, J., Zhang, W., Ping, S., Lu, W., Chen, M. \& Lin, M. (2008). Resistance of Deinococcus radiodurans to mutagenesis is facilitated by pentose phosphate pathway in the mutS1 mutant background. Curr Microbiol 57, 66-71.

Makarova, K. S., Aravind, L., Wolf, Y. I., Tatusov, R. L., Minton, K. W., Koonin, E. V. \& Daly, M. J. (2001). Genome of the extremely radiationresistant bacterium Deinococcus radiodurans viewed from the perspective of comparative genomics. Microbiol Mol Biol Rev 65, $44-79$.

Makarova, K. S., Omelchenko, M. V., Gaidamakova, E. K., Matrosova, V. Y., Vasilenko, A., Zhai, M., Lapidus, A., Copeland, A., Kim, E. \& other authors (2007). Deinococcus geothermalis: the pool of extreme radiation resistance genes shrinks. PLoS One 2, e955.
Marmur, J. \& Doty, P. (1962). Determination of the base composition of deoxyribonucleic acid from its thermal denaturation temperature. J Mol Biol 5, 109-118.

Owen, R. J. \& Lapage, S. P. (1976). The thermal denaturation of partly purified bacterial deoxyribonucleic acid and its taxonomic implications. J Appl Bacteriol 41, 335-340.

Oyaizu, H., Stackebrandt, E., Schleifer, K. H., Ludwig, W., Pohla, H., Ito, H., Hirata, A., Oyaizu, Y. \& Komagata, K. (1987). A radiationresistant rod-shaped bacterium, Deinobacter grandis gen. nov., sp. nov., with peptidoglycan containing ornithine. Int J Syst Bacteriol 37, 62-67.

Rainey, F. A., Ray, K., Ferreira, M., Gatz, B. Z., Nobre, M. F., Bagaley, D., Rash, B. A., Park, M. J., Earl, A. M. \& other authors (2005). Extensive diversity of ionizing-radiation-resistant bacteria recovered from a Sonoran Desert soil and the description of nine new species of the genus Deinococcus obtained from a single soil sample. Appl Environ Microbiol 71, 5225-5235.

Rainey, F. A., Ferreira, M., Nobre, M. F., Ray, K., Bagaley, D., Earl, A. M., Battista, J. R., Gómez-Silva, B., McKay, C. P. \& da Costa, M. S. (2007). Deinococcus peraridilitoris sp. nov., isolated from a coastal desert. Int J Syst Evol Microbiol 57, 1408-1412.

Sawabe, T., Makino, H., Tatsumi, M., Nakano, K., Tajima, K., Iqbal, M. M., Yumoto, L., Ezura, Y. \& Christen, R. (1998). Pseudoalteromonas bacteriolytica sp. nov., a marine bacterium that is the causative agent of red spot disease of Laminaria japonica. Int J Syst Bacteriol 48, 769774.

Shashidhar, R. \& Bandekar, J. R. (2006). Deinococcus mumbaiensis sp. nov., a radiation-resistant pleomorphic bacterium isolated from Mumbai, India. FEMS Microbiol Lett 254, 275-280.

Suresh, K., Reddy, G. S. N., Sengupta, S. \& Shivaji, S. (2004). Deinococcus indicus sp. nov., an arsenic-resistant bacterium from an aquifer in West Bengal, India. Int J Syst Evol Microbiol 54, 457-461.

Tamura, K., Dudley, J., Nei, M. \& Kumar, S. (2007). MEGA4: molecular evolutionary genetics analysis (MEGA) software version 4.0. Mol Biol Evol 24, 1596-1599.

Weisburg, W. G., Barns, S. M., Pelletier, D. A. \& Lane, D. J. (1991). $16 \mathrm{~S}$ ribosomal DNA amplification for phylogenetic study. J Bacteriol 173, 697-703.

Weon, H.-Y., Kim, B.-Y., Schumann, P., Son, J.-A, Jang, J., Go, S.-J. \& Kwon, S.-W. (2007). Deinococcus cellulosilyticus sp. nov., isolated from air. Int J Syst Evol Microbiol 57, 1685-1688.

Zhang, Y.-Q., Sun, C.-H., Li, W.-J., Yu, L.-Y., Zhou, J.-O., Zhang, Y.-O., Xu, L.-H. \& Jiang, C.-L. (2007). Deinococcus yunweiensis sp. nov., a gamma- and UV-radiation-resistant bacterium from China. Int J Syst Evol Microbiol 57, 370-375. 